変化しないとのことでした.被ばく線量低減に関して付加フィルタに よる方法との比較をすればと思います。なお，「体側フィル夕」という 呼称からはフィルタの目的, 働き, 取り付けなどをうまく表現してい るとは言い難いが…...?

このセッションは日常臨床の中で注意深い観祭からより良好な安 定した画像を求めて,さらに被ばく線量も低減しょうとして装置の改 良や器具を開発し，また，日常業務の再検討を行って扔り，臨床の場 において大変重要な事と考えます.今後とも, 臨床に適したものを追 求していただきたく思います。

\section{〔X線 CT〕}

\section{6. スパイラルスキャンの基礎的検討}

座長 天辰裕俊（宝塚市立病院）

兵庫医科大学病院中央放射線部

O梅原孝好・中江保夫・松木俊郎

堀 賣規・尾崎隆男・琴浦規子 谷川穂積

〔目的〕シーメンス社製 CT 装置 Somatom-plus に導入したスパ イラルスキャンについて,テーブルスピードとスライス厚の関係を検 討した.

〔方法〕スパイラルスキャン，シングルスキャンにて1. スライス 位置を傾斜ファントムを用いて確認する．2．傾斜ファントムを用い, スライス厚とテーブルスピードの関係について測定する．3．2 種の スキャン方法にて CT 值の変化を測定する.

〔結果〕1．スライス位置は2種のスキャン方法で大きな変化はな かった.2. スライス厚はスパイラルスキャンのほうが厚く,テーブル スピードによりスライス厚も変化する。

7. UInar carpal abutment syndrome $の$ 診断に適応する尺骨撮影 法

$$
\begin{aligned}
& \text { 星ヶ 丘厚生年金病院放射線部 } \\
& \text { 中嶋泰司・米岡敏雄・木村正明 } \\
& \text { 友森周三・本中 功・中島広視 } \\
& \text { 石原正仁 : 長畑 弘 }
\end{aligned}
$$

〔目的〕Ulnar variance の計測における尺骨撮影法の適応，お上 びそのデータの利用による ulnar carpal abutment syndrome，尺骨 頭背側脱臼の診断, 治療成績の向上。

〔方法〕Ulnar variance の計測のために, 尺骨撮影法, 手関節撮影 法, 前腕撮影法を行い, 一定の方法で計測し, 差を比較した。 また, 前腕の最大回内位, 最大回外位に抢ける手関節部の CT を撮像し雨者 を比較した。

〔結果〕Ulnar variance の計測には尺骨撮影法を選択し，そのデ 一夕を用いることにより診断, 治療成績の向上を認めた。また前脆の 最大回内位の CT 画像に扔いて, 尺骨頭背側脱臼を描出することがで きた。

\section{CT 検査における人工呼吸器配置の検討}

$$
\begin{gathered}
\text { 大阪府三島救命救急センター放射線科 } \\
\text { O渡部敬次・山本浩司・森原宗憲 } \\
\text { 西本武司・榊 芳則 }
\end{gathered}
$$

〔目的〕救命救急センターに搬入されてくる重傷患者には, 各種の 输液ポンプや心電図モニター, 人工呼吸器を必要とする場合が多く, 各種医療機器が CT 検查を実施するにあたって障害となり, 医療ス夕 ッフの作業性を低下させていると考元る. 今回, 特に障害となってい る人工呼吸器の配置について検討した。

【結果〕1. スタンド型人工呼吸器の本体のみを走查ガントりの前 後面に装着した.2. ガントリ周辺のスペースを有効利用でき, 作業範 囲の拡大が可能となり，作業性が向上した.3. 検查部位に応じた人工 呼吸器の配置・移動が容易になった。 4 . 人工呼吸器を装着した患者の CT 検查がスムースに行える上うになった。

\section{座長集約}

演題 6 は, 近年 CT 装置で話題となっているスパイラル(ヘリカル) スキャンのスライス幅, 位置および CT 值について従来のシングルス キャンと比較した結果を報告した.スライス位置と CT 值は両者に差 はないが，スライス位置に関してはスパイラスのほうが約1.4倍の厚 さになる(FWHM 法)という結果を得ていた。

質問 勝田 (大阪府立成人病センター) TOPO 画像と実際のスキャ
ン像の位置ずれを少なくする方法は？

答 目的部位より少し大きめに設定する.

質問 座長 1 . スライス位置が画像上の上下左右でずれる可能性 は. 2. スパイラルスキャンにおける問題点については.

答 1. 今回，中心でしか測定してないためはっきり言えないが可 能性はある. 2．スライス厚より大きい秒間テープル移動距離の設定 は画質的に難しい. 線量や再構成フィルタの選択自由度が少ない. ス ライスを補間再構成しているためスキャン中の被写体の動きによる アーチファクトが多いなどである。

演題 7 は, Ulnar carpal abutmant syndromeの診断に必要な ulnar variance の測定に適した撮影法について検討し，結果として Palmer 氏法による尺骨撮影が最適であるとしている，また，上記疾 患に付随して生ずる尺骨頭背側脱臼を CT にて描出したとの報告て あった。

質問 座長 1. 测定者間による誤差は. 2. 脱臼を生じるUnar variance は何 $\mathrm{mm}$ 以上加. 3. 測定值の最小単位は. 4. CT の保険適 用外疾患であるが

答 1.3 人で行ったが問題なし． 2 . 症例少なく分からないが， 2 $\mathrm{mm}$ の患者は脱臼していた. $3.0 .1 \mathrm{~mm}$ 単位. 4. 医師および患者協 議のうえで請求はしていない. 今後，MR の適用を考慮している.

演題 8 は, 人工呼吸器本体のみを CT 装置に装着可能にしたことで 検查時の作業スペースを拡大させたとの報告であった。

質問 遠藤 (近畿医療技術専門学校) 1. ガントリーの強度は.2．ガ ントリーの傾斜によって人工呼吸器の性能に変化は．3．ほかの機種 への応用は.

答 1.2 . 問題なかった. 3 . 検討課題である。 〔非相称フィルム】

9. 濃度加法性系の画像評価について 座長 小倉明夫（京都市立病院）

$$
\begin{aligned}
& \text { 国立福知山病院 } \\
& \text { ○若松孝司・山口正之・筒井孝彦 } \\
& \text { 松尾浩二・渡辺哲也 }
\end{aligned}
$$$$
\text { 近畿大学医学部附属病院 岡田弘治 }
$$

Lanex Medium+TMG の強度スケールによる特性曲線を片面ず つについて求めたところ, 前面乳剤と後面乳剤について感度おょび階 調度に差が出た。明らかに従来型のシステムについても非相称性が見 られる. 今後, 増感紙フィルム系の画像諭注非相称性に視点を当てて 論ずる必要がある.非相称系の諭点の中心になるのは浱度加法性であ る.前面と後面との濃度の加法性を認めるとき非相称系の見加け上の 総合 MTF は次式となる.

$\left(\mathrm{G}_{\mathrm{F}} / \mathrm{G}\right) \mathrm{MTF}_{\mathrm{F}}+\left(\mathrm{G}_{\mathrm{B}} / \mathrm{G}\right) \mathrm{MTF}_{\mathrm{B}}$

$\mathrm{G}$ ：総合階調度 $\mathrm{G}_{\mathrm{F}}, \mathrm{G}_{\mathrm{B}}$ ：前面および後面階調度

したがって総合 MTF は漂度低存性を有する。複雑な因子を有する非 相称系の画像評価に NEQ(u) は有効である.

10. Kodak Insight Thoracic Imaging System の特性について 神戸大学医学部附属病院中央放射線部

○吉岡有里・久保和広・小川静香 堤亜起子・岡山貴宣・今井方丈 西 政美・神澤良明・河野通雄

〔目的〕今回胸部専用感材として開発された非相称感材システム (Kodak Insight Thoracic Imaging System) の物理的特性（特性曲 線・MTF・Gradient Curve・RMS) について検討した。

〔方法〕本システムは，システム前面・後面それぞれ特性が異なる ため, 前面・後面各々について測定した，濃度加法性が成り立つこと から, H-D curve は, 前面·後面の測定値より作成し gradient curve はその H-D curveより求めた。 また MTF については，濃度依存性 を持つことより今回は， $\mathrm{D}=1.8$ として求めた。

〔結果〕本システムは, 低濃度領域は後面の特性により寛容度が大 きく, 高濃度領域は前面の特性により高コントラスト高鮮鋭度の新し い感材システムである.

11. 非相称フィルムの物理特性について 長浜赤十字病院放射線科部 $\bigcirc$ 野瀬一弘・松井久男・藤原将洋 松鴆弘幸・西関 魝・服部 昭 